\title{
Muslims in Georgetown World Heritage Site: Cultural and socio-economic sustainability
}

\author{
Jamalunlaili Abdullah¹, Rahmat Azam², \\ Reevany Bustami ${ }^{3}$, Che Bon Ahmad ${ }^{4}$ \\ 1 Faculty of Architecture, Planning and Surveying, \\ Universiti Teknologi MARA, 40450 Shah Alam, Malaysia \\ 2 School of Housing, Building and Planning, \\ Universiti sains Malaysia, Penang, Malaysia \\ *jamal858@salam.uitm.edu.my
}

\begin{abstract}
Georgetown World Heritage Site (GWHS) is known as a potpourri of various ethnic groups who have settled in the area during various periods of the past 300 years. Chinese are the majority although Muslims (Malays) were earliest settlers and once the majority. This paper analyzes the socio-economic and cultural sustainability of the Muslim community within the GWHS relying on historical records and current situation. Areas around masjid kapitan Kling and masjid Melayu are considered as the Muslim enclave. While the Indians Muslims are doing rather well socio-economically, the same cannot be said of the Malays. The number of Malays is very low and Malay business owners in the area tend to live outside the GWHS. The decline of the Muslim population has grave implications to the socio-economic and cultural sustainability of the Muslims, especially the Malays.
\end{abstract}

Keywords: Georgetown World Heritage Site, Muslim enclave, socio-economic, cultural sustainability

eISSN 2514-751X @ 2018. The Authors. Published for AMER ABRA CE-Bs by e-International Publishing House, Ltd., UK. This is an open-access article under the CC BY-NC-ND license (http://creativecommons.org/licenses/bync-nd/4.0/). Peer-review under responsibility of AMER (Association of Malaysian Environment-Behaviour Researchers), ABRA (Association of Behavioural Researchers on Asians) and cE-Bs (Centre for EnvironmentBehaviour Studies), Faculty of Architecture, Planning \& Surveying, Universiti Teknologi MARA, Malaysia.

DOI: https://doi.org/10.21834/aje-bs.v5i17.45 


\subsection{Introduction}

GWHS together with Melaka were accorded recognition by UNESCO for their multicultural city life which evolved for almost 5 centuries.GWHS is the most significant part of Georgetown due to its historical and heritage status. The area has witnessed much change, physically and socially over the centuries that it has existed.

\subsection{Literature Review}

During Georgetown development of almost 250 years, especially within the present UNESCO World Heritage Site, Muslim (Malays) was the earliest settlers and comprised a significant percentage of the population within the area and exerted much economic and political influence. They were the pioneers and the largest ethnic groups in Georgetown until the arrival of Chinese after the 1850s which was followed by Indians from South India which reached its peak around 1920s. Over the years, especially since 1960s, the significance of the Muslims within the GWHS in terms of the number and economic performance has been on the decline.

\subsection{Methodology}

This paper analyzes the historical development of the Muslims in Penang and their current situation. It focuses especially on an area known as the Muslim enclave within the GWHS, an area surrounding the Masjid Kapitan Kling and Masjid Melayu Leboh Acheh.

The paper is based on a descriptive analysis relying on historical records of the Muslims within the GWHS. This is done to provide understanding of the rise and decline of the Muslim community within the GWHS.

\subsection{Results and Discussion}

Through analysis of various historical documents, it was ascertain the Muslims were the earliest inhabitants of the present site Georgetown and Penang Island. Also, over the years they were the largest group until the arrival of the Chinese in large number since the mid-19th Century.

During Georgetown development of almost 250 years, especially within the present UNESCO World Heritage Site, Muslim (Malays) was the earliest settlers and comprised a significant percentage of the population within the area and exerted much economic and political influence. When Francis Light landed at Point Penaga (now called Fort Cornwalis) in 1786 he found a small population of Malays (about 30) who were led by Nakhoda Kechil. There was also a group of 58 Malays found collecting gum-damar a short distance inland and he also found a small remnant of Malays at Dato' Keramat. The enterprising Chulias soon came from South India as well as from Kedah. Tengku Syed Hussein, an Achehnese leader from Sumatra, settled in Penang in 1792 and founded the Masjid Melayu, or Acheen Street Mosque. There were about 300 Acehnese traders who lived in this community in the mid-19th Century. The group was politically active and powerful that Gedung Aceh was the 
meeting place of the Council of Eight, the Acehnese resistance against the Dutch in the 1870.

The Muslims then were generally of the Malay descents as well as those who hailed from South India. In 1833 the Muslims comprised about 66 percent of the Penang Island (Prince of Wales Island) population. The Malays alone accounted for 16,435 people which were 41 percent of Penang island population of 40,322 (Braddell, 1861). The Indian Muslims who were among the earliest settlers in Penang had a significant population $(9,208)$ that surpassed that of the Chinese population (8751). In 1863, the Chuliahs $(7,886)$ and the Bengalese (1322) constituted 23 percent of the population in Penang. It was a significant group from South Asia especially since Hindu laborers from India immigrated in larger number than the Muslims only after the first hundred years, specifically towards the end of $19^{\text {th }}$ Century and early $20^{\text {th }}$ Century. The Indian Muslims settled mostly around Kapitan Kling Mosques on Chulia Street which also boast of a number of Indian Muslim mosques and keramat such the Nagore shrine (early 1800s) and the Noordin tomb (1870s). Ibrahim Munshi, the son of Abdullah Munsyi, who visited Penang in 1872 remarked that the area around Kampung Masjid Melayu and Chulia Street had a large ethnically mixed Muslim community.

In the late $19^{\text {th }}$ Century and early $20^{\text {th }}$ Century, pilgrims from northern Malaya, southern Thailand and northern Sumatra would come to Penang before boarding ships to perform their hajj in Mecca. Consequently, many lodges were developed around Acheen Street. There could be found Arab traders, sheikh hajis, Minang food vendors and Rawa textile and book traders plying their trades. Table 1 and 2 below shows the population of Muslims and their economic activities in Georgetown from 1794 until 1900.

Table 1: Muslim Population and their Economic Activities, 1794 -18331

\begin{tabular}{lllll}
\hline Location & Muslim Group & Activities & Year & Additional Notes \\
\hline Georgetown & 1000 & Trade/business & 1794 & $\begin{array}{l}\text { Some of them supplied } \\
\text { hand manufactured } \\
\text { tobacco-products such }\end{array}$ \\
& & & $\begin{array}{l}\text { as cigars, (beedi) and } \\
\text { snuff-powder }\end{array}$
\end{tabular}

\begin{tabular}{lllll}
\hline Georgetown & $\begin{array}{l}3,446 \\
\text { (Chuliahs) }\end{array}$ & Business & 1833 & \\
\hline Georgetown - Datok & 30,435 & Agriculture, & 1833 & $\begin{array}{l}\text { The businesses } \\
\text { include Small- \& } \\
\text { Keramat, Jalan Perak, } \\
\text { Lebuh Leith, Port }\end{array}$ \\
$\begin{array}{l}\text { Cornwallis, Jalans) } \\
\text { Armanien. }\end{array}$ & Fisherman, Business & & $\begin{array}{l}\text { Medium-size } \\
\text { Enterprises (SMEs) }\end{array}$
\end{tabular}

\begin{tabular}{llll}
\hline Georgetown & 1,322 (Bengalese) & Business & 1833
\end{tabular}


Abdullah, J., et.al. / Asian Journal of Environment-Behaviour Studies (ajE-Bs), 3(9) Jul / Aug 2018 (p.75-83)

\begin{tabular}{lllll}
\hline Lebuh Armenians & $\begin{array}{l}214 \\
\text { (Arabs/ Parsees/ } \\
\text { Armenians) }\end{array}$ & Business & 1833 & $\begin{array}{l}\text { publication of } \\
\text { newspaper and books }\end{array}$ \\
\hline $\begin{array}{l}\text { Lebuh Aceh/ Lebuh } \\
\text { Leith/ Datok Keramat }\end{array}$ & $\begin{array}{l}347 \\
\text { (Achinese) }\end{array}$ & Business & 1833 & \\
\end{tabular}

(Source: Straits Settlement Report of Penang 1800 -1900 and Manuscript of Light Letters)

Table 2: Census of the Population of Prince of Wales' Island and the places subordinate and its Annexed areas (Prince of Wales' Island, 31st Dec. 1833)

\begin{tabular}{ll}
\hline Europeans and their descendants & 789 \\
\hline Armenians & 21 \\
\hline Malays & 16,435 \\
\hline Achinese & 347 \\
\hline Battahs & 561 \\
\hline Chinese & 8,751 \\
\hline Chuliahs & 7,886 \\
\hline Bengalese & 1,322 \\
\hline Siamese and Burmese & 648 \\
\hline Arabs & 142 \\
\hline Parsees & 51 \\
\hline Native Christians & 708 \\
\hline Caffres & 180 \\
\hline Native Military and followers & 678 \\
\hline Convicts, including local prisoners & 1,263 \\
\hline Average number of Patients, in the Chinese Poor House, & 140 \\
Lunatic Asylum, and Native Pauper Hospital & \\
\hline ltinerants supposed here about this season & 400 \\
\hline TOTAL & 40,322 \\
\hline
\end{tabular}

Source: Straits Settlement Report of Penang 1800-1900

It was very clear that Muslims were the dominant group in Georgetown during at least the first half of development of Georgetown after the landing of Francis Light. However, land law changes initiated by the British had caused them to lose some of their land to the British and other ethnic groups. This, coupled by their lack of capitals and understanding of the concept of capitalism brought about by the British had caused them to be marginalized economically. In addition, urban renewal projects initiated by the government and organizations had caused the number of Muslims to reduce significantly over the years. The loss of Penang free port status and the change of hajj mode of transport from sea-shipping to air planes were two other momentous events that negatively impacted the number and socio-economic conditions of the Muslims within the GWHS.

The number of Muslim population started to dwindle from the 1840-1870 period when much of the Muslim settlements at Acheen and Armenian Street were bought over by Straits Chinese merchants. Cheah Kongsi, followed by other Hokkien clan associations such as the Yeoh, the Khoo, the Lim and the Tan, started to purchase properties from the Muslims and moved into the area. They bought up large plots of land to build their clan temples and 
surrounding row houses for their clansmen.

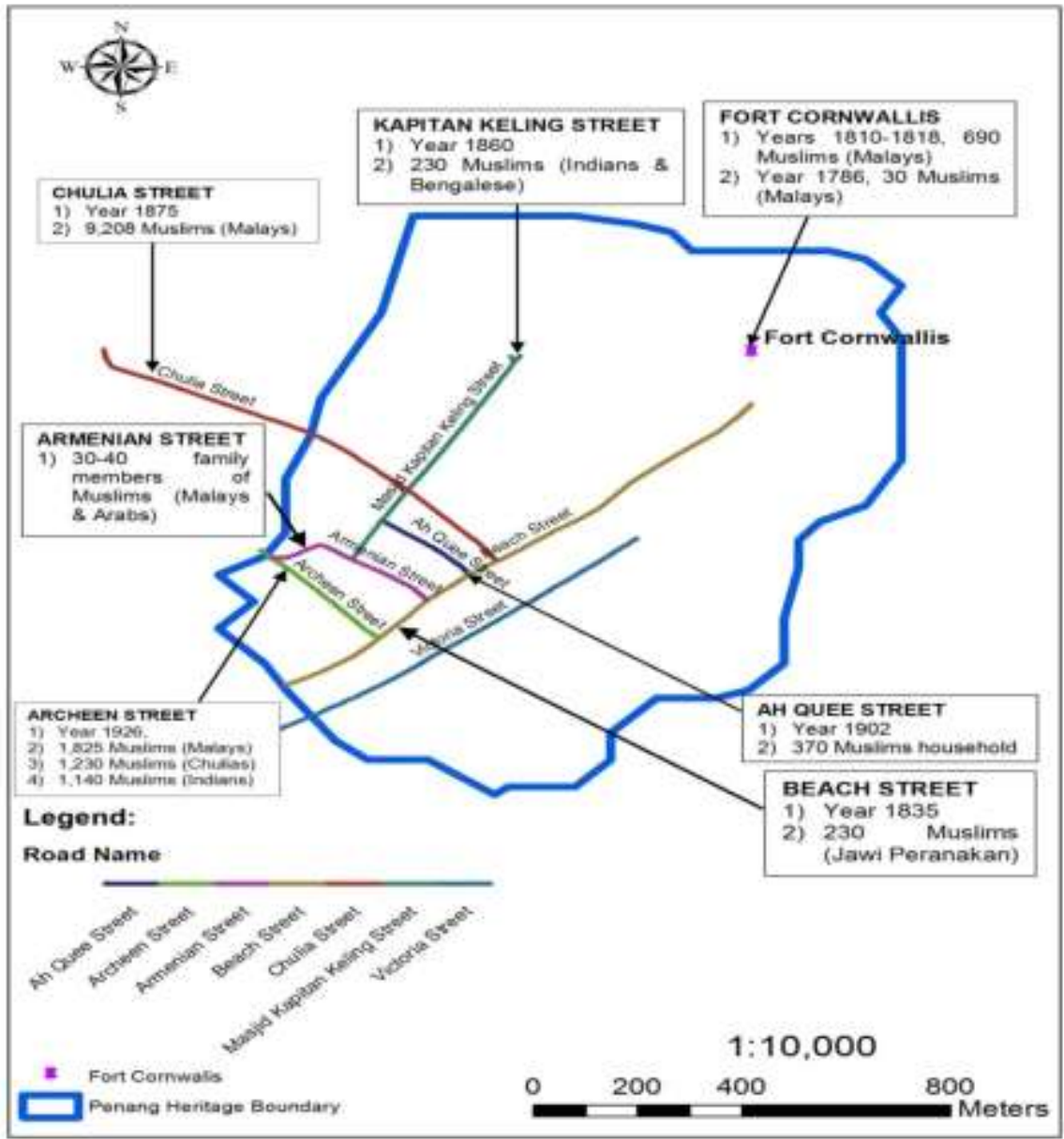

Figure 1: Temporal (Historical) and Spatial Spread of Muslim Community in Penang World Heritage Site (Core Zone

Table 3: Malay Population in Penang $(1786-1860)^{2}$

\begin{tabular}{ll}
\hline Year & Malay \\
\hline 1786 & 100 \\
\hline 1812 & 6,504 \\
\hline
\end{tabular}


Abdullah, J., et.al. / Asian Journal of Environment-Behaviour Studies (ajE-Bs), 3(9) Jul / Aug 2018 (p.75-83)

\begin{tabular}{ll}
\hline 1820 & 8,681 \\
\hline 1830 & 11,943 \\
\hline 1842 & 18,442 \\
\hline 1850 & 16,570 \\
\hline 1860 & 8,887 \\
\hline & Source: Adapted from Braddell (1861)
\end{tabular}

The Muslim Endowment Board undertook a large scale urban renewal project from 1900s to 1930 whereby houses in the Kapitan Kling Mosque compound and adjacent Kampung Kolam and Kampung Kaka were cleared. Kampung Taka and Kampung Wahab were also cleared at the turn of the century to create Ah Quee Street and Lumut Lane, respectively. With airplanes replacing ships as the mode of transportation to perform haj since the 1970s and Penang losing its free port status, the number of Muslim population within the UNESCO World Heritage Area has dwindled.

Currently Malays constitutes 9.7 percent of the population while Indians (which comprise mostly Hindu and Muslim) constitutes 13.1 percent. Even the small percentage of the Malay population is boosted by a number of policemen and their families living in the police quarters. Socio-economically, the situation of the Muslims seems worse especially compared to that of the Chinese. Marginalization of the Muslim community is due to several factors. The first is due to the Muslim's socio-cultural dynamics and need for money. One of the factors Muslims' moving out from urban areas is their own social-cultural dynamics. This is a key narrative about the phenomenon of land marginalization, especially local Muslims. The dynamics include the value-system and prioritization placed on properties relative to their social and familial needs interwoven with their religious duties and cultural obligations.

New politico-legal environment also had pushed the Muslims from owning lands which they had worked on for years. These include Leith Proclamations. On $21^{\text {st }}$ February and $6^{\text {th }}$ October 1801, two proclamations on land policy were made by George Leith. They covered matters pertaining to land purchase, land mortgage, will-writing and estate redistribution. The proclamations required the government to call back all forms of land title documents for the purposes of reviewing, updating and correcting errors before the issuing of new grants. This move had made land transfers from the ownership of locals (including local Muslims) to foreigners and non-locals much easier and in effect contributed to a substantial number of legal grant transfers. The proclamations changed the legal landscape of land ownership.

In addition, the dominance of European land ownerships had overwhelmed the Malays and other Asians. Europeans obtained not only large area of lands but also lands in more valuable areas. A large part of their lands were under grant titles before leasing system was introduced.

There are a number of reasons why Europeans possess high levels of ownership even at the early stages of their stay. A prominent reason is that Penang Island did not have many buildings for them to settle in. Therefore, their administrators and officers had to acquire lands to build their dwellings. As for those Europeans engaged in trade and commerce, lands were also needed to erect shops and offices for their business operations. Another reason why the Europeans and Eurasians were in possession of many large plots of lands, despite their small number, was the goal of the government to turn Penang into a production zone for a selected 
food and export items. A number of English men who had aspirations for agricultural ventures actually obtained large pieces of lands to fulfill this colonial goal.

The capital imperative played a pivotal role in favoring the Europeans in land acquisition. At the early period of English settlement, lands in Penang Island were not priced as high. What that meant was that the cash-rich Europeans had high purchasing power. As the policy on land ownership was indeed liberal, colonial administrators and officers with financial strength were in position to amass real estate properties. Land owners also did not have to pay high taxes or adhered to strict rules.

Unfavorable institutional environment also had caused many Malays to lose their land to the cash rich Europeans. In 1805, historical records show confusion on the part of relevant state land authorities on issues of land management, land granting and land ownership in Penang. Subsequently, in April 1808, the then Governor of Penang issued a statement of concern about the decreasing number of productive land use in the state. Disappointed by the failure of receiving land titles for the farms they had cultivated for a long time (in some case even after ten years), many hardworking farmers had left their lands. This disappointment is worsened by declining prices of agricultural commodities. Many of these were local Muslimsi. The institutional practices were unfavorable and punishing to them. The process to obtain land ownership titles took too long in addition to the high tax burden if they were to register the lands. New laws on land took effect on $28^{\text {th }}$ April 1809. The board of directors issued a new directive allowing Penang state to continue granting new land titles. Among the regulations is that each new grant given to an applicant by the State could not exceed 50 'relongs'. Furthermore, the size of land was to be given in accordance to the capacity of the applicant.

All ethnic groups including Europeans were allowed to own these state-given lands. The lands not in use for a certain period of time will be taken back and return to the State. Taxes on the land were also imposed. The State also required registration fees to be paid for issuing of land grant titles. All these new factors and impositions contributed to the locals being marginalized in this new market environmentii. Yet it was in part the non-competitive and accommodating nature of local Muslims, and by extension the business community MECC, that allowed other groups to take root and to benefit from their stay in Penang Island. Nevertheless, the process and forces of marginalization had taken place.

In addition to the above conditions, urban development undertaken by the governments and organizations had also negatively impacted the Muslim community. As stated earlier, large scale urban renewal projects undertaken by the Muslim endowment Board had uprooted some Muslim residents. Houses in the Kapitan Kling mosques compound and adjacent Kampung Kolam and Kampung Kaka were cleared. The creation of Ah Quee Street and Lumut Lane had cleared Kampung Taka and Kampung Wahab, respectively at the turn of the $20^{\text {th }}$ Century. These were the areas were Muslims were numerous. Where they were relocated to after that is unclear.

\subsection{Conclusion}

This paper has analyzed the socio-economic situation of an area known as the Muslim 
enclave within the GWHS. It has shown that the Muslim population within the GWHS was once the pioneers and the largest ethnic group in Georgetown. However, due to several factors, their significance, demographically and socio-economically, has declined over the years. It is imperative an Action Plan be instituted to bring the Muslim enclave and its people to its former glory.

\section{Acknowledgement}

The authors are grateful to Think City Sdn Bhd (Khazanah Nasional) for funding a consultancy of which this paper is based.

\section{References}

Ahmad Adam, (2009) Letters of Sincerity: The Raffles Collection of Malay Letters (1780-1824) A Descriptive Account with Notes and Translation, MBRAS Monograph 43 (Bandar Puchong Jaya: MBRAS, 2009)

Anderson, John, 'Political and Commercial Considerations Relative to the Malayan Peninsula and the British Settlements in the Straits of Malacca', 8 JIAEA (1854) 134-157, 266-284, 365-372; 1 JIAEA (1856) NS 299-315; 35 JMBRAS (1962) Part IV; Introduction by John Bastin 1-10.

Bassett, D.K. (1961). 'The British Country Trade and Sea Captain in South East Asia in the Seventeenth and Eighteenth Century', Journal of the Historical Society University of Malaya) 1, no. 2:9-14.

Bassett, D.K. (1964) 'British Commercial and Strategic Interest in the Malay Peninsula during the Late Eighteenth Century', in Bastin, J. and Roolvink, R (eds) Malayan and Indonesian Studies: Essays Presented to Sir Richard Windstedt on His Eighty-fifth Birthday (London: Oxford University Press), 122-140.

Bastin, John, 'Historical Sketch of Penang in 1794', 32 JMBRAS (1959) Part 1, 1-32,

Blagden, CO, 'Notes on Malay History', 53 JSBRAS (1909), 139-162.

Cheah Boon Keng (ed.) New Perspectives and Research on Malaysian History (Essays on Malaysian Historiography), Monograph 41 (Bandar Puchong Jaya: MBRAS, 2007

Clodd, H.P. (1948). Malaysia's First British Pioneer: The Life of Francis Light with a Foreword by Sir Richard Windstedt (London: Luzac \& Co)

Cullin, E.G. and Zehnder, W.F. (1905). The Early History of Penang 1592-1927 (reprinted from The Straits Echo). Penang: The Criterion Press Ltd.

Francis Light Papers. Archive and Manuscript Collection, SOAS, University of London.

Neil Khor Jin Keong and Malini Das. (2002). Glimpses of Old Penang. Petaling Jaya: Star Publications. Society, 2004).

Nabir Haji Abdullah. (1993). 'Dasar Tanah Kerajaan di Pulau Pinang, 1786-1840-an: Perkembangan dan Masalah Pentadbirannya' Ph.D thesis Universiti Sains Malaysia, Penang.

Omar Farouk Shaeik Ahmad, The Arabs in Penang, Malaysia in History, Vol 21: No 2, December 1978, 1-16. 
Abdullah, J., et.al. / Asian Journal of Environment-Behaviour Studies (ajE-Bs), 3(9) Jul / Aug 2018 (p.75-83)

Ahmad Jelani Halimi, Perdagangan dan Perkapalan Melayu di Selat Melaka: Abad ke-15 Hingga Ke-18 (Kuala Lumpur: Dewan Bahasa dan Pustaka, 2006).

Penang Historical Society, (1965), Penang Past and Present 1786-1963. Penang: Penang Historical Society.

Popham, H. (1805) A Description of Prince of Wales Island in the Straits of Malacca: With its Real and Probable Advantages and Sources to Recommend it as a Marine Establishment (London: John) 